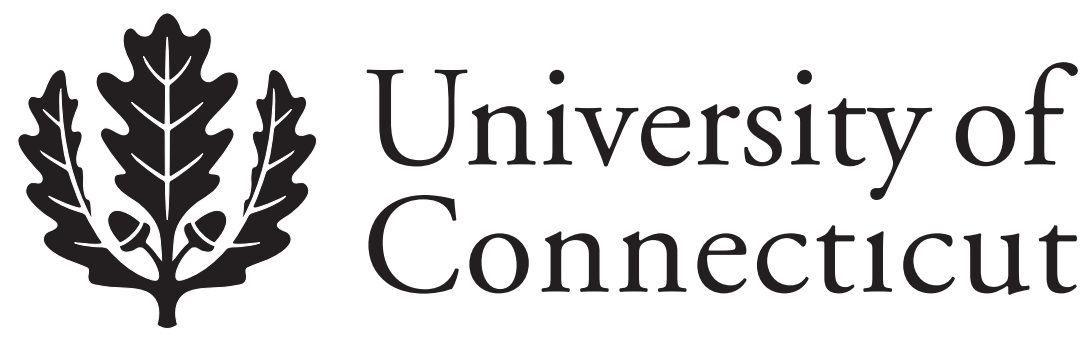

Department of Economics Working Paper Series

\title{
Voting in Kenya: Putting Ethnicity in Perspective
}

Michael Bratton

Michigan State University

Mwangi S. Kimenyi

University of Connecticut

Working Paper 2008-09

March 2008

341 Mansfield Road, Unit 1063

Storrs, CT 06269-1063

Phone: (860) 486-3022

Fax: (860) 486-4463

http://www.econ.uconn.edu/

This working paper is indexed on RePEc, http://repec.org/ 


\begin{abstract}
Do Kenyans vote according to ethnic identities or policy interests? Based on results from a national probability sample survey conducted in the first week of December 2007, this article shows that, while ethnic origins drive voting patterns, elections in Kenya amount to more than a mere ethnic census. We start by reviewing how Kenyans see themselves, which is mainly in non-ethnic terms. We then report on how they see others, whom they fear will organize politically along ethnic lines. People therefore vote defensively in ethnic blocs, but not exclusively. In Decem- ber 2007, they also took particular policy issues into account, including living standards, corruption and majimbo (federalism). We demonstrate that the relative weight that individuals grant to ethnic and policy voting depends in good part on how they define their group identities, with "ethnics" engaging in identity voting and "non-ethnics" giving more weight to interests and issues.
\end{abstract}

Journal of Economic Literature Classification: D72, D74, D78

Keywords: Democracy, Elections, Kenya, Ethnic Divisions, Ethnic Conflict. 


\section{Introduction}

Post-election violence in Kenya paints a picture of a country severely fractured by ethnic cleavages. The conflicts following the disputed December 2007 presidential election in many respects mirror the character of violence that preceded the 1992 and 1997 general elections. The cycle of violence around elections in Kenya appears to support views expressed by the first generation of independent African leaders, who argued that Africa was best suited for single party systems of governance because multipartyism would result in increased tribalism. ${ }^{1}$ Yet it would be unwise to jump to the conclusion that Africans are not ready for democratic competition. Not only do most Africans abhor violence and seek to peacefully participate in the selection of their own leaders. But African elections - including Kenya's December 2007 contest - reveal that voters consider factors other than ethnicity in deciding how to vote.

To be sure, ethnicity has played a central role in Kenyan politics as evidenced by patterns of political mobilization, resource allocation, and public service appointments, notably to the Cabinet (Kimenyi 1997; Orvis 2001; Apollos 2001). The introduction of multiparty politics in 1991 brought ethnic politics to the fore as opposition parties quickly splintered according to ethnic groupings (Kimenyi 1997; Muigai 1995). As a result, the first multiparty election held in 1992 was a contest that largely rotated around ethnic alignments, a pattern repeated in the 1997 general elections (Oyugi 1997). Nevertheless, the view that voting in Kenya is simply a cultural phenomenon was weakened in the 2002 general election when a broad coalition of ethnic groups supported Mwai Kibaki. ${ }^{2}$

The comparative literature on mass electoral behavior can be viewed as a debate on the relative importance of social identities or economic interests (Lichbach and Zuckerman 1997). For advanced democracies, elections tend to take the form of a referendum on the economy, with voters rewarding or punishing incumbent political parties at the ballot box depending on their past policy performance (Lewis-Beck and Stegmaier 2000, Geys 2006). Evidence of this sort of retrospective, interest-based economic voting has also been found in Latin America and other parts of the developing world (Remmer 1991; Pacek and Radcliff 1995). More commonly, however, voters in new democracies and deeply divided societies are held to rely on cultural attachments when deciding how to vote. Horowitz coined the term "ethnic census" to describe elections in which racial, linguistic or tribal solidarities so strongly predict voting behavior that elections are little more than a head count of identity groups (1985; see

\footnotetext{
${ }^{1} \mathrm{~A}$ common explanation for the 1992 and 1997 violence is that it aimed to weaken the voting strength of the opposition especially in the Rift Valley. This political explanation is supported by the fact that such conflicts subsided after the elections (see Kimenyi and Ndung'u 2005). Unlike these past episodes, violence in 2007 was after the elections. However, there was no notable violence either before or after the 2002 elections.

${ }^{2}$ But even in this case, ethnic voting cannot be easily dismissed. The main contenders for presidency were from the same ethnic group. Because the other candidate (Uhuru Kenyatta) was aligned with the then ruling party Kenya African National Union (KANU), the coalition that supported Kibaki might have been motivated more by desire to dislodge a common rival from power.
} 
also Kalipeni 1997, Nugent 2001).

The best recent work on this subject indicates how identities and interests can coexist and reinforce. Chandra shows that voters in India consider the size of the ethnic group that each party represents as a means of calculating the likelihood of gaining access to patronage (2003). With reference to settings as diverse as Spain, Ecuador and Romania, Birnir argues that ethnic groups compete peacefully in elections (rather than resorting to violence) when they perceive opportunities to secure places for their representatives within decisionmaking institutions, including the Cabinet (2007).

The debate between identities and interests is alive and well in studies of African elections. In a cross-national study of 12 African countries, Norris and Mattes find that ethnicity and linguistic cleavages are important in explaining an individual's support for parties in power in most, but not all, places (2003). Identity voting is strongest in ethnically fragmented societies, but popular evaluations of government performance in service delivery are also important in influencing voting choices. Other analysts point out that retrospective assessments of the condition of the national economy or future expectations of personal economic wellbeing have even trumped ethnicity in selected elections in Zambia and Ghana (Posner and Simon 2002; Youde 2004; Lindberg and Morrison 2008). With reference to South Africa, Ferree finds only weak support for expressive voting based on identity alone, but also no support for policy-based interest voting (2004; see also Mattes and Piombo 2001; Erdmann 2007). Instead, she posits the insightful argument that voters use information on the assumed ethnic identities of parties, casting ballots for those they expected to best defend their group interests in a context where others are assumed to vote along identity lines.

We therefore expect to find that ethnicity will be an important factor in explaining electoral choices in Kenya, but only as one among several relevant determinants of partisanship. Whereas people will vote according to their ethnic origins, they will also care about policy interests such as personal economic wellbeing, the performance of the economy, and the government's policy record in select issue areas. In confirming the above hypotheses, we also discover that ethnic voting contradicts Kenyans' views of themselves as adherents to a national (Kenyan) identity. Furthermore, the importance of ethnicity seems to vary depending on respondent's self-ascribed identity, with "ethnics" more often employing feelings of group identity and "non-ethnics" more often making rational calculations of personal and group interest.

\section{Data}

Claims about the dominance of ethnic voting are usually based on broad generalizations arising from analysis of aggregate national data that are not well suited to revealing voter intentions. Fortunately, researchers have recently begun to conduct representative sample surveys on voter attitudes and behavior in Africa. By drilling down to the individual level, it becomes possible to test generalizations about the effects of ethnic origins and ethnic identity on voting and to weigh these factors against other expressed and inferred motivations for electoral choices. This article relies on data from a survey of eligible voters 
in Kenya (aged 18 years and older), which was carried out three weeks before the December 27, 2007 general election. Sponsored jointly by the Center for the Study of African Economies (CSAE), Oxford University and the Afrobarometer, the survey was implemented by trained enumerators in all 8 provinces and in 76 out of Kenya's 210 electoral constituencies. ${ }^{3}$ The nationally representative sample of adult Kenyans comprised 1207 respondents.

To ensure national representation, the sample was designed such that 65 percent of respondents were from rural areas and the remainder was from cities and towns. A number of challenging field conditions affected the execution of the survey such that the final sample was to some extent biased towards persons of higher socio-economic status. Importantly, however, the ethnic distribution of the sample respondents is correct. As Table 1 shows, the distribution of ethnic groups in the sample closely mirrors that of the population of Kenya. [Table 1 about here]

\section{How Kenyans See Themselves}

Do Africans just see themselves in ethnic terms? Unlike in "traditional" societies, where the self image of an individual overlaps almost exclusively with that of the tribal group, in modernizing societies, individuals have multiple identities and interests, each of which can be expected to contribute to their political preferences. To ascertain how Kenyans see themselves, we began by asking for a self-ascribed group identity. The question was phrased as follows: "We have spoken to many Kenyans and they have all described themselves in different ways. Some people describe themselves in terms of their language, ethnic group, race, religion or gender and others describe themselves in economic terms, such as working class, middle class or a farmer. Besides being Kenyan, which specific group do you feel you belong to first and foremost?"

When asked to depict their group identity in this way, few Kenyans opt for an ethnic appellation. As Table 2 shows, only one out of five (20 percent) volunteers an answer that refers to clan, tribe, language, race or sub-national geographical region. Instead, more than twice as many Kenyans (totaling 43 percent) elect non-ethnic identities, notably those based on occupation (18 percent), social class ( 7 percent), gender (4 percent) and religion (3 percent). Moreover, disregarding the interviewer's instruction to consider only specific sub-group attachments, some 37 percent of respondents insisted on identifying themselves first and foremost as Kenyans, that is, in terms of national identity.

To enable further analysis, we will label these segments of the population as "ethnics," "non-ethnics," and "Kenyans." The purpose ultimately is to test whether self-ascribed identity has formative effects on popular attitudes and behavior, especially voting behavior. For the moment, however, we simply note that the evidence in Table 2 makes it difficult to sustain for Kenya the conventional argument that Africans automatically define themselves by means of cultural solidarities. Instead, the respondents to our survey apparently prefer

\footnotetext{
${ }^{3}$ The authors thank Roxana Gutierrez Romero of CSAE for managing survey fieldwork.
} 


\begin{tabular}{|l|l|l|}
\hline \hline \multicolumn{2}{|c|}{$\begin{array}{r}\text { Table 1:Distribution of Ethnic Groups } \\
\text { in sample and Population }\end{array}$} \\
\hline \hline Ethnic Group & Sample percent & National Population \\
Share & & \\
\hline \hline Kikuyu & 18.7 & 20.78 \\
Luhya & 15.7 & 14.38 \\
Luo & 12.3 & 12.38 \\
Kalejin & 8.5 & 11.46 \\
Kamba & 9.3 & 11.42 \\
Kisii & 8.0 & 6.15 \\
Meru & 8.2 & 5.07 \\
Mijikenda & 6.2 & 4.70 \\
Maasai & 2.2 & 1.76 \\
Turkana & 2.1 & 1.32 \\
Embu & 1.1 & 1.20 \\
Taita & 1.9 & 0.95 \\
Teso & 0.2 & 0.83 \\
Kuria & 0.1 & 0.52 \\
Basuba & 0.1 & 0.50 \\
Samburu & 0.1 & 0.50 \\
Arab & 0.2 & 0.16 \\
Somali & 3.1 & 0.21 \\
Swahili & 0.5 & 0.37 \\
Pokot & 1.0 & 0.37 \\
Bajun & 0.20 & 0.26 \\
Nubi & 0.2 & - \\
Borana & 0.1 & 0.31 \\
\hline \hline Data are based on the 1989 Kenya Population \\
Census (Nairobi, Central Bureau of Census) \\
\hline \hline
\end{tabular}




\begin{tabular}{|l|l|l|}
\hline \hline \multicolumn{2}{|c|}{ Table 2:Preferred Group Identities, Kenya 2007- N=1207 } \\
\hline \hline Label & Choice & Percent \\
\hline "Ethnics" & $\begin{array}{l}\text { Clan, tribal, linguistic, } \\
\text { racial, and regional identities }\end{array}$ & 20 \\
"Non-Ethnics" & $\begin{array}{l}\text { Class, occupational, } \\
\text { gender religious and other personal identities }\end{array}$ & 43 \\
\hline \hline
\end{tabular}

\begin{tabular}{|l|l|}
\hline \multicolumn{2}{|c|}{ Table 3:Ethnic Versus National Identities, Kenya 2007 } \\
\hline \hline Identity & Percent \\
\hline I feel only Kenyan & 22 \\
I feel more Kenyan than (respondent's ethnic group) & 29 \\
I feel equally Kenyan and (respondent's ethnic group) & 35 \\
I feel more (respondent's ethnic group) than Kenyan & 12 \\
I feel only (respondent's ethnic group) & 2 \\
\hline \hline N =637. Excludes "don't know" and "not applicable" \\
i.e. insisted on Kenyan identity \\
\hline \hline
\end{tabular}

to choose among the wide repertoire of social and economic identities that is on offer in a complex, modernizing society.

Nor are group identities fixed. Depending on the situation, individuals may activate different collective personae. For example, we find no evidence that group and national identity are mutually exclusive. Rather, these alternatives are arrayed on a continuum, which allows for various admixtures. Table 3 displays the results when respondents were posed a hypothetical dilemma: "Let us suppose you had to choose between being Kenyan and being (the identity of the respondent's ethnic group). Which of the following statements best expresses your feelings?" A plurality of one third prefers to strike a coequal balance between cultural and national identity by saying "I feel equally Kenyan and ethnic." But when moving off the fence, many more Kenyans opt for national above ethnic group identity (51 percent versus 14 percent). Once again, Kenya does not seem to fit the African stereotype of an ethnically driven society, at least as far as the self-depictions of citizens are concerned.

Certainly, Kenyans wish to see themselves as blind to ethnic prejudice in interpersonal relations. Only 6 percent admit to always choosing friends whose ethnic background is the same as their own. And just 16 percent say that, among friends and acquaintances from various parts of the country, they "prefer people of the same ethnic background." Instead, a clear majority of more than three out of four Kenyans (77 percent) asserts that, "my friendship with a person is not at all affected by his or her ethnic background." Of course, one can question the extent to which such expressed sentiments are driven by the respondent's 


\begin{tabular}{|l|l|}
\hline \hline Table 4: Self-Described Voting Motivations, Kenya 2007 \\
\hline \hline The preferred candidate would: & Percent \\
\hline Actually serve the community & 27 \\
Be honest in handling public funds & 25 \\
Care about the community & 22 \\
Have experience at managing public services & 19 \\
Have a high education level & 4 \\
Have a chance of winning the election & 1 \\
Belong to my ethnic group & less than 1 \\
Other & 2 \\
\hline
\end{tabular}

effort to appear socially acceptable or politically correct. But, at minimum, this distribution of responses about friendship indicates the prevalence of norms in Kenyan society requiring tolerance of ethnic diversity.

These sentiments carry over into the political realm. More people agree than disagree that, "political parties should not be allowed to form on an ethnic or regional basis" (57 versus 33 percent, with the remainder not knowing or feeling neutral). And a plurality, admittedly narrow, agrees that, "there should be more parties representing people from different ethnic, tribal, religious or language groups" (46 versus 40 percent).

The most striking evidence of a popular desire for non-ethnic politics concerns people's self-appraised reasons for making a choice at the polls. The survey asked respondents to select the qualification "most important to you when you decide whom to vote for in a presidential election." The most frequent answers concerned the candidate's expected service to the community (27 percent) and honesty in handling public funds (25 percent) (See Table 4). Noteworthy for our purposes here, however, fewer than 1 percent of all respondents $(10$ persons out of 1207) said that the most important consideration was that the candidate "belongs to my ethnic group." Political scientists have long known that voters are poor judges of their own political motivations and that survey research is a blunt instrument for revealing real voting rationales. But the strength of this result leads to only two possible conclusions: either voting in Kenya is genuinely non-ethnic, or Kenyans are describing their political world in a way they want it to be, rather than the way it really is. We consider the latter possibility in the sections that follow.

\section{How Kenyans See Others}

Although Kenyans downplay ethnicity when portraying themselves, they are less charitable in their assessments of fellow citizens. Our survey reveals that Kenyans do not easily trust co-nationals who hail from ethnic groups other than their own. They also think that political conflict is all too common among people of different ethnic backgrounds, especially in the national political arena. Finally, they worry that their co-nationals are prone to organize politically along 


\begin{tabular}{|l|l|}
\hline \hline \multicolumn{2}{|c|}{ Table 5: Interpersonal Trust by Social } \\
Distance, Kenya 2007 \\
\hline \hline Response* & Percent * \\
\hline Trust your relatives & 39 \\
Trust your neighbors & 18 \\
Trust people from your own ethnic group & 13 \\
Trust people from other ethnic groups & 8 \\
\hline N $=1207^{*}$ Percent saying, "I trust them a lot." \\
\hline \hline
\end{tabular}

exclusive ethnic lines and to govern in discriminatory fashion. As a starting point, let us review the extent of interpersonal trust among our survey respondents. In reply to a question about "how much do you trust each of the following types of people?" respondents grant most confidence to those in their immediate social circle. As per Table 5, four out of ten Kenyans (39 percent) express "a lot" of trust in people to whom they are related by blood or marriage, with and additional 50 percent expressing at least "a little" trust in relatives. From this baseline, the radius of trust declines sharply as people gauge how much trust to place in non-kin and strangers. Some 18 percent are willing to extend a lot of trust to the people who live in their local neighborhood and 13 percent would do the same for unknown individuals from their own ethnic group. But, importantly, fewer than one in ten (8 percent) express a lot of trust in Kenyans from other ethnic groups (though only 14 percent trust other ethnics "not at all").

The pattern by which interpersonal trust diminishes with social distance is a common feature of the way that all ethnic groups in Kenya view the wider world. In Kenya, we detect a slight tendency for Embu and Meru people to be more trusting of other ethnic groups than the Luo (12 percent versus 5 percent). Otherwise, any differences across the country's main ethnic groups are minor.

A similar concentric pattern prevails for popular perceptions of social discord. Respondents were asked, "in your opinion, how often do violent conflicts arise between (various) people (in Kenya)?" As in Table 6, hardly anyone (3 percent) reports that such conflicts occur "often" or "always" within their own families. But the proportions acknowledging frequent social strife increase steadily as the social circle widens: in their own communities, some 6 percent of respondents see violent conflicts within ethnic groups and some 15 percent between ethnic groups. But fully 46 percent of Kenyans consider that violent conflicts occur "often" or "always" among different groups in the national arena.

As might be expected, there is a correlation at the individual level between distrust for other ethnic groups and perceptions of high levels of inter-ethnic conflict. We interpret this linkage to mean that Kenyans are inclined to assume that strangers mean trouble rather than to reach more generous conclusions.

Kenyans also regard ethnicity as a source of political and economic division. The survey asked, with reference to various social characteristics, "how often, if ever, are people in Kenya discriminated against?" Very few Kenyans feel 


\begin{tabular}{|c|c|}
\hline \multicolumn{2}{|l|}{$\begin{array}{c}\text { Table 6: Perceived Violent Conflict } \\
\text { by Social Distance, Kenya } 2007\end{array}$} \\
\hline Source & Percent* \\
\hline Conflict within your own family & 3 \\
\hline Conflict within ethnic group in your community & 6 \\
\hline Conflict between ethnic groups in your community & 15 \\
\hline Conflict between ethnic groups in this country & 46 \\
\hline
\end{tabular}

that individuals face discrimination for being old (10 percent), for being young (16 percent), or for professing a particular religious faith (18 percent). But somewhat larger proportions see discrimination based on language (22 percent) and ethnic group (25 percent). And fully 39 percent, mainly women, point to gender as the main basis of perceived discrimination in Kenya.

Although this sort of felt ethnic grievance is fairly widespread, being evident to some extent among members of most ethnic groups, there are statistically significant differences between major clusters: for example, members of groups from Western Kenya, such the Luo and Luhya are twice as likely to express a sense of ethnically based discrimination than groups from Central Kenya such as those in the Kikuyu-Embu-Meru complex or the Kamba (on average, 16 percent versus 8 percent).

Kenyans often trace the source of any felt ethnic discrimination to the performance of the central government. In this case, the gap in perceptions between people of Kikuyu and Luo heritage is profound. As Table 7 shows, these two groups display starkly different views about the even-handedness of governance in Kenya. People of Luo origin are five times more likely than people of Kikuyu origin to see their group's economic conditions and influence in national politics as worse than others'. And they are ten times more likely to attribute this state of affairs to discrimination by incumbent officeholders in the nation's central government. In the starkest distinction of all, Luo are twenty-five times more likely than Kikuyu to say that government treats their ethnic group unfairly. While these figures graphically portray the divergent perceptions of different identity groups, they also raise the analytic puzzle of whether discrimination is best attributed to ethnic origin or policy performance, or to some combination thereof.

We close this section by drawing attention to the political and electoral implications of perceived ethnic differences. In Kenya, as in other personalized polities in Africa, ordinary people often judge the fairness of the political system with reference to the ethnic character of the political elite. Despite protestations that a candidate's tribal identity does not enter into the voting calculus (see previous section), citizens acknowledge that an ethnic division of spoils is an important (if unspoken) subtext in national electoral contests.

This observation is confirmed in Table 8 by the weight that survey respondents attribute to the ethnic origins of candidates in the voting calculations of 


\begin{tabular}{|l|l|l|}
\hline \hline \multicolumn{3}{|c|}{$\begin{array}{c}\text { Table 7: Perceived Government Discrimination } \\
\text { by Major Ethnic Group, Kenya 2007 }\end{array}$} \\
\hline \hline $\begin{array}{l}\text { Ethnic } \\
\text { Group }\end{array}$ & $\begin{array}{l}\text { Kikuyu } \\
\text { percent }\end{array}$ & $\begin{array}{l}\text { Luo } \\
\text { percent }\end{array}$ \\
\hline Group's economic conditions worse than others* & 12 & 64 \\
\hline $\begin{array}{l}\text { Group's influence in national } \\
\text { politics worse than others'* }\end{array}$ & 5 & 25 \\
\hline $\begin{array}{l}\text { Group's treatment by government } \\
\text { worse than others'* }\end{array}$ & 6 & 66 \\
\hline $\begin{array}{l}\text { Ethnic group treated unfairly } \\
\text { by government** }\end{array}$ & 2 & 52 \\
\hline \hline $\begin{array}{l}\text { N=1207. * Percent saying "worse" or "much worse" } \\
* * \text { Percent seeing this treatment "often" or "always" }\end{array}$ \\
\hline \hline
\end{tabular}

\begin{tabular}{|c|r|}
\hline \hline \multicolumn{2}{|c|}{ Table 8: Perceived Salience of Candidate's } \\
Ethnicity in Recent Elections, Kenya 2007 \\
\hline \hline Election & Percent* $^{*}$ \\
\hline \hline 1997 election & 37 \\
2002 election & 30 \\
2007 election & 50 \\
\hline \hline
\end{tabular}

other Kenyans. With reference to 2002, when the National Rainbow Coalition (NaRC) swept into power at the head of a pan-ethnic coalition, less than a third of respondents (30 percent) saw the ethnicity of candidates as an important consideration for the electorate. A larger proportion (37 percent) acknowledge that ethnicity was a factor in the 1997 election, a contest that was preceded by ethnically targeted, state-sponsored violence in the Rift Valley and marked by an opposition fragmented along ethnic and other lines. But Kenyans apparently see the December 2007 general election as the most polarized contest of all; half of all survey respondents (50 percent) say that the ethnic origin of candidates was an important consideration for their fellow citizens, including for those trying to decide who to vote for. By this time, the NaRC coalition had broken down and the presidential race had crystallized into a Kikuyu-Luo tussle over the presidency.

Nonetheless, as the 2007 election approached, Kenyans continued to insist that they would make their voting decisions on grounds of rational self-interest, that is, with attention to policy issues rather than ethnic identities. When asked to describe how they would decide "which political party you like most," they claimed to give top priority to "the policies the party promises to implement" (70 percent said they considered this factor "a lot"), "the personal integrity of the party's leader" (66 percent) and " the past governing experience of the party" (55 percent). Only one out of five made similar mention of "the ethnic or regional origins of the party's leader" (20 percent). 
But we cannot ignore the persistent salience of ethnic considerations. It may well be that, while voters would prefer to vote on issues rather than identities, they worry that their opponents will not do the same. In another context, Ferree has argued that:

"a 'racial heuristic' approach offers the best explanation for South African voting behavior. South African voters, like voters everywhere, use cognitive shortcuts to guide their voting decisionsthey evaluate parties based on their 'racial credentials' - the groups they believe the parties support and favor (and) the groups they believe the parties opposeAfricans who see the opposition as exclusive (i.e. white) are more likely to hold positive views of the (ruling) ANC's performance" (forthcoming 2008, 10).

In similar vein, Posner has noted for Zambia:

"The fact that so many survey respondents told me that tribalism was wrongdoes not imply that it is absent either from their calculations or from their behavior. Despite their preference for a situation in which resources are not distributed along ethnic lines, they find themselves trapped in an equilibrium where ethnic favoritism is the rule, and where they lose out in access to resources if they ignore its implications for political behavior" $(2005,104)$.

Our survey results contain evidence of this form of reasoning. When we ask Kenyans about the characteristics of "the political party you most dislike," they cite its "poor or unrealistic policies" (65 percent) and "the party leader's association with corruption" (63 percent). But almost as strong is their concern about " the party's perceived tribalism" (59 percent). In other words, voters refer to the institutional reputation of their opponent's party in deciding, defensively, to vote as an ethnic bloc. They do not need to be primarily motivated by their own ethnic origins in order to behave in this fashion; they only need fear that their opponents will rely on formulae of ethnic exclusivity. Where voting blocs are polarized, and where polarization revolves around ethnicity, voters are hard pressed to maintain a commitment to policy issues above ethnic origins as a basis for voting.

\section{How Kenyans Vote}

This section of the paper turns from political attitudes to political behavior. We wish to know whether social identity or economic interest - or some combination of the two - is the driving force behind the political choices made by voters in Kenya's December 2007 presidential election. Specifically, we test whether Kenyans formed an intention to vote for the incumbent president, Mwai Kibaki, on the basis of ethnic origins or policy issues.

So far, we have reported the attitudes of a representative cross section of adult Kenyans, all of whom are eligible voters. From this point forward, the 
paper uses a more restricted segment of the data by reporting intended vote choices only for "likely voters," that is, people who said that they were both registered to vote and who planned to cast a ballot in the 2007 general elections. This group of 1096 individuals constitutes some 91 percent of survey's original sample. To avoid confounding the analysis, we do not wish to include the political preferences of people who were not on the voters' roll or had no intention of voting.

The overall results of the vote choice analysis are presented in Table 9 by means of a series of logistic regression models. To repeat, the dependent variable is the probability that, in a survey three weeks before the December 2007 election, an individual reported an intention to vote for Kibaki. To discover the best predictors of this outcome, we gradually and sequentially introduce various combinations of independent variables representing either the voters' ethnic origins or their policy preferences. If any of these factors prove to have explanatory power, they are retained in subsequent models; if they do not, they are trimmed out.

Model 1 assumes that elections in Kenya are a mere ethnic census. In other words, this model predicts that all we need to know about vote choice is the voter's stated answer to the question "what is your tribe?" For simplicity's sake, data are reported for Kenya's eight largest ethnic groups - Kikuyu, Luhya, Luo, Kamba, Kalenjin, Embu/Meru, Kisii and Mijikenda - which together make up 87 percent of the ethnic origins cited both by respondents in the survey and the national census. Other minority ethnic groups are excluded from the analysis.

The first conspicuous result is how well Model 1 actually works. It demonstrates the feasibility of predicting more than one half of the variance (r square $=.514$ ) in the intended presidential vote with reference to ethnic origins alone. Because each ethnic group is scored as a dummy variable - that is, on a 0 to 1 binary scale - it proves possible to compare the relative political salience of particular cultural groups to voting behavior. With reference to the raw regression coefficients (B), we can see that the strongest effects of ethnicity are for people in the Kikuyu-Embu-Meru complex and the Luo and Kalenjin clans. But, as the contrasting signs on the coefficients indicate, Kikuyu and colleagues are strongly likely to vote for the incumbent president but the Luo and allies are strongly inclined to vote against him. On the basis of this powerful evidence, it would be foolish to deny that voting in Kenya has an ethnic foundation.

But we suspect that there is more to voting than ethnicity alone. In a crossnational analysis for twelve African countries, Bratton, Mattes and GyimahBoadi:

"find that ethnicity is significantly associated with vote choice in just over half of the Afrobarometer countries. As such, cultural, linguistic and hometown ties remain critical elements in the calculus used by African electors to choose their leadersIt would be mistaken, however, to conclude that elections in contemporary Africa amount to little more than an ethnic census. Ethnic-linguistic identity plays no significant role in vote choice in five countries in the Afrobarom- 
eter sample, all of which rank low in ethnic votingIndeed, for all countries studied, vote choice is first and foremost a product of popular performance evaluationsWhat matters most to voting for the winning party is whether people think that the national president has done a good job" (2005, 307).

Kenya provides a critical test case for this generalization. We have already shown that public opinion about government performance is deeply divided in Kenya, giving rise to a nagging sense of political grievance in some ethnic quarters and a concomitant air of ethnic entitlement elsewhere. If policy issues can be shown to contribute to a voter's choice in a presidential election in Kenya, then interest-based considerations are likely to matter for voting in virtually any African country.

Model 2 introduces an initial test of issue-based voting. It employs a summary indicator of presidential performance: "do you approve or disapprove of the way that the following people have performed their jobs over the past twelve months: President Kibaki?" One is immediately struck by the fact that Kibaki receives positive performance ratings, not only from his co-Kikuyu but also from a range of ethnic groups. Even among people of Luo origin, approval of Kibaki's performance stood at 44 percent, which was well above his disapproval rate of 14 percent.

Moreover, a model that includes this indicator is more effective than the original formulation that rested on a list of ethnic groups alone. The amount of explained variance increases by some 20 percent (to r square $=.619$ ). Moreover, when presidential approval (as a proxy for policy issues) is considered on its own, it explains a sizeable amount of variance ( $\mathrm{r}$ square $=.436)$. To be sure, policy issues measured in this way do not trump ethnic origins but they demand to be included in any comprehensive account of the way Kenyans vote.

As an aside, it is worth noting that, statistically, the introduction of presidential performance renders Luhya ethnic origins insignificant. One possible interpretation is that, for this ethnic group, careful considerations of President Kibaki's performance outweigh any knee-jerk tendency to vote automatically as an ethnic bloc. Similarly, the addition of presidential performance to Model 2 reduces the probability of bloc voting for people from major ethnic groups like the Kikuyu, Luo, Kalenjin and, especially, the Embu-Meru. As such, we have prima facie evidence that, with the possible exception of people of Kamba origin, the presence of policy issues in an election campaign dilutes the impact of an ethnic census for almost all voters in Kenya.

But which policy issues? In Model 3, we enter voters' estimates of Kibaki's performance (compared to that of former president, Daniel arap Moi) on nine specific policy dimensions. The question was phrased thus: "Looking back, how do you compare President Kibaki's performance with President Moi's performance with regard to the following matters?" The list of nine policies ranges from "the economic condition of the country" and "your living standards" to "reforming the constitution" and "tackling crime."

Once disaggregated in this way, three policy issues turn out to be conse- 
quential: living standards, school expenses, and corruption. Since coming to power in 2002, Kibaki's government is credited for reviving the economy, which registered annual growth rates of above 4 percent since 2003, a marked improvement from the Moi years. Several sectors, especially services and agriculture, have continued to record impressive gains. The ensuing growth has resulted in broad-based improvements in quality of life, especially in rural areas. Likewise, Kibaki's government honored its campaign pledge to provide free primary education, which again benefited the population across the nation. Although President Kibaki was criticized for not doing enough to fight corruption, many also acknowledge that he accomplished much especially in reforming the judiciary and establishing and strengthening anti-corruption agencies. These three issues appear to have influenced some voters to support the incumbent.

On the other hand, some expected issues turned out to be damp squibs: jobs, crime and constitutional reform. While the country experienced impressive growth, job creation fell below expectations and unemployment rates of young people continued to rise, especially in urban areas. Furthermore, civil servants and teachers received large pay increases. Crime has long been a concern for many Kenyans: while success in fighting crime was recorded during Kibaki's first term, gang-related crime escalated. But neither jobs nor crime appears to have motivated a vote for Kibaki.

We also expected that constitutional reform would be an issue to divide voters. Some Kenyans see the President as reneging on a 2002 promise to share power and as responsible for derailing the adoption of a constitution that the majority of the population preferred. Others give him credit for having made genuine efforts to change the constitution, even though he could not win support in a 2005 referendum for a version that retained many centralized presidential powers. By 2007, it appears that constitutional issues were not considered pivotal in the presidential election, which is surprising since power-sharing issues immediately resurfaced once the credibility of the election was called into question. $^{4}$

Let us note that, as further evidence of the need to supplement the ethnic census model, the specification of policy issues renders Kalenjin ethnicity statistically insignificant. This move also further reduces the strength of the effects of Kikuyu, Embu/Meru and Luo ethnic origins. We make two further adjustments in the trimmed Model 4. First, in search of parsimony, we remove all ethnic groups and policy issues that have not achieved statistical significance.

Second, in search of further explanatory power, we add a policy issue that rose to prominence during the 2007 election campaign. Known as "majimbo," it revived a debate from the independence era about whether Kenya should be a unitary or federal state. As a campaign issue, the opposition Orange Democratic Movement advocated the decentralization of political power to Kenya's outlying provinces from the capital city of Nairobi (and by implication, from the Kikuyudominated highlands of Central Province). A clear majority of Kenyans thinks

\footnotetext{
${ }^{4}$ For a detailed discussion of voting in the 2005 Kenyan constitutional referendum, see Kimenyi and Shughart, 2008
} 


\begin{tabular}{|c|c|c|c|c|}
\hline \multicolumn{5}{|c|}{$\begin{array}{l}\text { Table 9: Logistic Regression Analysis: Probability } \\
\text { of Voting for Mwai Kibaki in the } 2007 \text { General Elections }\end{array}$} \\
\hline Explanatory Variable & Model 1 & Model 2 & Model 3 & Model 4 \\
\hline N (Likely Voters Only) & 1096 & 1087 & 952 & 1005 \\
\hline Explanatory Variables & $\mathrm{B}(\mathrm{sig})$ & $\mathrm{B}(\operatorname{sig})$ & $\mathrm{B}(\operatorname{sig})$ & $B(\operatorname{sig})$ \\
\hline Constant & $-6.16(.000)$ & $-4.908(.000)$ & $-5.993(.000)$ & $-5.805(.000)$ \\
\hline Ethnic Origins & & & & \\
\hline Kikuyu & $2.829(.000)$ & $2.587(.000)$ & $2.570(.000)$ & $2.483(.000)$ \\
\hline Embu/Meru & $2.642(.000)$ & $1.703(.000)$ & $2.287(.000)$ & $1.985(.000)$ \\
\hline Luo & $-2.691(.000)$ & $-2.037(.000)$ & $-1.709(.000)$ & $-1.853(.001)$ \\
\hline Kamba & $-.871(.005)$ & $-.915(.007)$ & $-1.141(.002)$ & $-1.264(.001)$ \\
\hline Kalejin & $-1.140(.001)$ & $-.749(.043)$ & $-.604(.153)$ & $-.550(.169)$ \\
\hline Luhya & $-.563(.032)$ & $-.219(.459)$ & $-.009(.977)$ & $-.93(.802)$ \\
\hline Kisii & $-.440(.166)$ & $-.472(.219)$ & $-.187(.670)$ & \\
\hline Mji Kenda & $-.463(.166)$ & $-.472(.219)$ & $-.187(.670)$ & \\
\hline Policy Issues & & & & \\
\hline Approve & & & & \\
\hline Kibaki's Performance & & & & \\
\hline Overall & & $1.408(.000)$ & & \\
\hline Economy & & & $0.39(.753)$ & \\
\hline Living standards & & & $.560(.000)$ & $.602(.000)$ \\
\hline Jobs & & & $.131(.259)$ & \\
\hline School expenses & & & $.264(0.23)$ & $.253(.014)$ \\
\hline School quality & & & $.0 .34(.745)$ & \\
\hline Roads and bridges & & & $0.153(.163)$ & \\
\hline Corruption & & & $0.299(.009)$ & $.398(.000)$ \\
\hline Constitutional reform & & & $0.93(.570)$ & \\
\hline Crime & & & $.102(.829)$ & \\
\hline Anti-majimbo & & & & $.371(.000)$ \\
\hline Nagelkerke R-Square & 0.514 & 0.619 & 0.639 & 0.648 \\
\hline Ethnic Origins Only & & .514 & & \\
\hline Policy Issues Only & & .436 & & \\
\hline
\end{tabular}




\begin{tabular}{|l|l|}
\hline \hline \multicolumn{1}{|c|}{\begin{tabular}{c}
\multicolumn{1}{|c|}{ Table 10: Popular Interpretations of } \\
"Majimbo", Kenya 2007 N=1207
\end{tabular}} \\
\hline \hline $\begin{array}{l}\text { Interpretation of Majimbo } \\
\text { Each tribe will have } \\
\text { its own government }\end{array}$ & Percent \\
\hline $\begin{array}{l}\text { Each province will } \\
\text { be autonomous }\end{array}$ & 10 \\
\hline $\begin{array}{l}\text { People living outside their homelands } \\
\text { will return to where they came from }\end{array}$ & 22 \\
\hline $\begin{array}{l}\text { Regions will control their own } \\
\text { resources as well as those distributed by central government }\end{array}$ & 51 \\
\hline Don't know & 1 \\
\hline \hline
\end{tabular}

that "the central government has too much power" (60 percent) versus a smaller minority who worry that "majimbo would threaten the unity of the country and should be avoided" (36 percent). Table 10 shows that half of all adult Kenyans see majimbo as a code word for redistributive politics. But it also reveals that almost one quarter interpret the policy as requiring that "people living outside their homelands will return to where they came from." In an eerie portent of conflicts to come after the election, and perhaps fearing that they might be targeted in any future ethnic cleansing, some 43 percent of Kikuyu interpret majimbo in these troubling terms.

For present purposes, however, we note that adding majimbo to our list of policy issues further strengthens the overall explanation (the variance explained in Model 4 is .648). The positive sign on the coefficient indicates that individuals who prefer centralized government (i.e. who oppose majimbo) have an increased probability of voting for Kibaki.

\section{Different Strokes for Different Folks}

The previous section established the importance of policy considerations as a complement to the ethnic structure of voting in Kenya. But the analysis so far has treated the national electorate as if voters all share the same mixed set of voting motivations. Yet we know from their self-ascribed group identities that Kenyans see themselves in differentiated ways: some describe their group identities in ethnic terms, others in non-ethnic terms, and still others refuse to adopt a sub-national identity, insisting instead that they are first and foremost "Kenyans."

Do different identity groups display distinctive voting patterns? The working hypotheses are the obvious ones. We expect that Kenyans who hold ethnic identities would be inclined to vote mainly according to their ethnic origins. By contrast, those who define themselves in occupational or class terms would give precedence to policy issues in their voting decisions. What is less clear is the voting calculus of people who insist on expressing only a national identity. Are 
"Kenyans" a new breed of policy voter or are they closet tribalists?

Table 11 records results when the survey sample is split according to the expressed group identities of the respondents. In Model 5, we first examine the voting behavior of self-described "ethnics," that is, people who point to clan, tribe, language, race or region as the focal point of their identity. As one would expect, this model of voter behavior is driven by ethnic origins: the ratio of explanatory power of ethnicity to policy is 515: 410 (or 1.26: 1).

But there are two important caveats. First, the ethnic origins of KikuyuEmbu-Meru people propel a vote for Kibaki, while the ethnic origins of Luo determine a vote against him. Yet, for the first time in any model, people of Kamba origin seem to be motivated more by policy considerations than by ethnic origins. In this instance, where the voting calculus of "ethnics" is considered in isolation, the main axis of ethnic relations in Kenya is laid bare along a divide between Kikuyu and Luo.

Second, few policy issues are salient for "ethnics." Most importantly, and unlike other citizens, "ethnics" do not refer to the performance of the president in raising living standards or controlling corruption when deciding for whom to vote. Instead, people who profess an ethnic identity distinctively focus on the issue of school expenses, presumably approving President Kibaki's actions to make good on his 2002 campaign promise to provide universal free primary education. For reasons that remain imperfectly understood (but perhaps because of their lower socio-economic status, see next section) "ethnics" (but not other Kenyans) identify educational finance policy as a reason to vote for the incumbent. Finally, as might be expected, we find that a preference for centralized government (a stance against majimbo) appeals to "ethnics," especially among Kikuyu.

Model 6 examines the voting behavior of self-described "Kenyans." This is the strongest model of all since it explains nearly three quarters of the variance in intended votes for a sitting president ( $\mathrm{r}$ square $=.740$ ). Given this exhaustive result, it seems unlikely that there are many other unspecified factors that could dethrone an explanation based jointly on ethnic origins and policy issues. Moreover, this model is the first in the series in which more than half the variance in vote preference can be attributed simply to policy considerations ( $\mathrm{r}$ square $=.509$ ). On one hand, therefore, a plausible account of "Kenyan" voting behavior could be constructed on the basis of policy interests alone.

On the other hand, one cannot discount ethnic origins quite so easily. The complete model puts ethnic and policy considerations in proper perspective, with the former leading the way. The ratio of ethnic origins to policy issues in this case is 624:509 (or 1.23:1). In other words, policy issues are only slightly more important for "Kenyans" than for "ethnics." And given margins of sampling and other error in survey data, it is safer to argue that self-described "Kenyans" are no less likely to be motivated by ethnic origins than are selfprofessed "ethnics." Moreover, we notice that among so-called "Kenyans", ethnic origins propel voting behavior only for the Kikuyu-Embu-Meru groups and for the Kamba. By contrast, those Luo who regard themselves as "Kenyans" make no reference to their ethnic origins when making voting decisions. Does 
this mean that the Kikuyu and related tribes equate their own ethnicity with national identity? Are they hinting that they see themselves as the only true Kenyans?

Model 7 reveals original results. It looks at the voting behavior of people who identify themselves in "non-ethnic" terms. For the first time in the entire modeling exercise, policy issues trump ethnic origins in determining how this group of citizens votes. The ratio of explanatory power between ethnicity and policy drops below unity to 450:505 (or 0.89:1). Once again, but this time without serious challenge from an ethnic counter-argument, more than half the variance in voting behavior can be traced to voters' policy interests. According to these results, "non-ethnics" - more so than any other identity group place high value on the performance of the incumbent regime at raising living standards and controlling official corruption. They insist that an elected government implements rational economic policies that deliver effective and efficient services.

We conclude the analysis of voting in Kenya with a final comment about ethnicity. Model 7 suggests that, even among "non-ethnics," people in the Kikuyu-Embu-Meru complex still vote as an ethnic bloc. Model 8 removes these voters from the analysis. Under these conditions, ethnic voting falls away almost completely ( $\mathrm{r}$ square $=.081$ ). The only ethnic marker that remains statistically significant is Kamba. In the December 2007 presidential election, even selfdescribed "non-ethnic" Kamba voted decisively for their regional favorite son, Kalonzo Musyoka.

In place of a predominantly ethnic explanation, however, we are left with a model in which policy issues explain more than one-third of the variance in vote choice $(\mathrm{r}$ square $=.354$ ). The most notable change is that, among "nonethnics" of Luo, Luhya, and Kalenjin origin, cultural origins are superseded by policy concerns. And among these concerns, the most compelling policy issue is the decentralization of political control over development resources. [Table 11 about here]

\section{The "Kenyans" and the "Non-Ethnics"}

An argument can be made that political development at the level of the mass electorates in Africa involves a transition from a politics based on cultural identity to a politics based on rational policy choice. If so, there are signs that some portions of the Kenyan electorate are undergoing such a transition. Our analysis has shown that people who self-identify as "Kenyans" already include policy considerations in their voting calculus. Furthermore, people who see their group identities in "non-ethnic" terms usually put policy issues uppermost.

By way of postscript to this analysis, and in order to understand the prospects for further political development in Kenya, we should probe: who are these people? Unfortunately, answering this question proves harder than expected. We find that interest-driven policy voters are a product of broad social, economic, and geographical changes. Our conclusions are suggestive rather than definitive; 


\begin{tabular}{|c|c|c|c|c|}
\hline \multicolumn{5}{|c|}{$\begin{array}{l}\text { Table 11: Logistic Regression Analysis: Probability } \\
\text { of Voting for Mwai Kibaki in the } 2007 \text { General Elections }\end{array}$} \\
\hline Explanatory Variable & Model 5 & Model 6 & Model 7 & Model 8 \\
\hline $\mathrm{N}$ (Likely Voters Only) & 201 & 373 & 431 & 261 \\
\hline Typology & "Ethnics" & "Kenyans" & "Non-ethnics" & $\begin{array}{l}\text { Non-Ethnics } \\
\text { w/o } \\
\text { Kikuyu } \\
\text { Embu-Meru }\end{array}$ \\
\hline Explanatory Variables & B(sig) & B(sig) & $\mathrm{B}(\operatorname{sig})$ & $\mathrm{B}(\operatorname{sig})$ \\
\hline $\begin{array}{l}\text { Constant } \\
\text { Ethnic Origins }\end{array}$ & $-5.168(.000)$ & $-6.053(.000)$ & $-5.916(.000)$ & $-6.286(.000)$ \\
\hline Kikuyu & $2.532(.000)$ & $4.860(.000)$ & $1.579(.000)$ & \\
\hline Embu/Meru & $2.373(.002)$ & $2.895(.000)$ & $.458(.446)$ & \\
\hline Luo & $-1.979(.002)$ & $-1.492(.087)$ & $-1.791(.009)$ & $-1.1416(.097)$ \\
\hline Kamba & $-858(.141)$ & $-1.348(.036)$ & $-2.104(.002)$ & $-1.390(.033)$ \\
\hline Kalejin & $-1.151(.322)$ & $-.755(.319)$ & $-6.49(.171)$ & $-.777(.310)$ \\
\hline Luhya & $.346(.629)$ & $-.385(.493)$ & $0.587(.204)$ & $-.153(.738)$ \\
\hline Kisis & & & & \\
\hline Mji Kenda & & & & \\
\hline Policy Issues & & & & \\
\hline Approve & & & & \\
\hline Kibaki's Performanc & & & & \\
\hline Overall & & & & \\
\hline Economy & & & & \\
\hline $\begin{array}{l}\text { Living standards } \\
\text { Jobs }\end{array}$ & $0.82(.743)$ & $.601(.004)$ & $.733(.000)$ & $.556(.009)$ \\
\hline School expenses & $.551(.019)$ & $1.02(.600)$ & $.190(.220)$ & $.165(.430)$ \\
\hline School quality & & & & \\
\hline Roads and bridges & & & & \\
\hline Corruption & $.392(.099)$ & $.429(0.16)$ & $.540(.000)$ & $.410(.037)$ \\
\hline $\begin{array}{l}\text { Constitutional reform } \\
\text { Crime }\end{array}$ & & & & \\
\hline Anti-majimbo & $.333(.011)$ & $.498(.000)$ & $.327(.000)$ & $.563(.000)$ \\
\hline Nagelkerke R-Square & 0.635 & 0.740 & 0.623 & 0.403 \\
\hline Ethnic Origins Only & .515 & .624 & .450 & .081 \\
\hline Policy Issues Only & 410 & .509 & .505 & .354 \\
\hline
\end{tabular}


but they point the way to additional research.

In terms of social forces, we hypothesize that intermarriage across cultural lines helps to explain the emergence of "non-ethnic" and "Kenyan" identities. In fact, absolute rates of intermarriage are quite low in Kenya: just 16 percent for the respondents in the 2007 survey and just 12 percent for their parents. These figures compare unfavorably with 1990 estimates of 46 percent for urbanites and 32 percent for rural dwellers reported for Zambia (Posner, 2005, 92). But, in Kenya, members of the current generation are more likely to intermarry if their parents did $(\mathrm{r}=.257, \mathrm{sig}=.000)$. Intermarriage among parents turns out to be the more influential factor: while it does not predict "non-ethnic" identity, it is significantly related to "Kenyan" identity $(\mathrm{r}=.064$, sig. $=.027)$. At minimum a mixed tribal parentage would seem to inhibit individuals today from lapsing into purely "ethnic" identities and behaviors.

An alternative hypothesis would suggest that interest-based policy voting is an economic phenomenon. Stated differently, "non-ethnicity" and nationality ("Kenyan-ness") may be class identities produced by the attainment of higher socioeconomic status. At first, the evidence seems unsupportive. There is no relationship between these identities and an individual's level of formal education, employment status, or subjective sense of wellbeing. Quite the contrary, an objective index of material assets - an additive scale of up to 15 consumer products - is almost perfectly orthogonal to seeing oneself as "non-ethnic" ( $\mathrm{r}=$ .000 , sig $=.998)$. But we do detect a class component to "Kenyan" identity, which is negatively related to an index of poverty based on lack of access to basic human needs like cash, food, water and medical care $(\mathrm{r}=-.071$, sig. $=.016)$. In other words, there is trace evidence that the transition from cultural to policy voting is linked to upward economic mobility.

The last possibility we consider is geographical. Although larger proportions of "non-ethnics" reside in Nairobi and Central Province than other provinces, there is no systematic connection between being urban and eschewing an "ethnic" identity. Instead, people escape their cultural identities and adopt broader horizons when they travel away from their places of birth. If people currently reside in the province they were born in, let us call them "homebodies" (72 percent). The relationship is positive between homebody status and electing an "ethnic" identity. By contrast, people who reside in a non-natal province let us call them "migrants" (28 percent) - are likely to identify themselves as "non-ethnic" $(\mathrm{r}=0.53$, sig. $=.064)$. Moreover, certain occupations, including several associated with working away from home - farm worker, artisan in the formal sector, businessperson (especially those employed by others), and teacher - are disproportionately taken up by "non-ethnics." The fact that these occupations are governed by market relations suggests that the abandonment of ethnic identities and the emergence of policy voting are twin products of both geographical and economic mobility. 


\section{Conclusions}

If the recent post-election violence signals strong ethnic identification, our analysis confirms it. Although Kenyans resist defining themselves in ethnic terms, their actions in making electoral choices show a country where voting patterns hew largely to ethnic lines. Respondents also show a high degree of mistrust of members of other ethnic groups and consider the behavior of these other groups to be influenced primarily by ethnicity. In general, voting in Kenya is therefore defensively and fundamentally an ethnic census.

Nevertheless, policy indicators concerning the performance of the incumbent government also matter in influencing voters' choices. Considerations of economic self-interest matter most for those individuals who define their identities in "non-ethnic" (but also non-national, i.e. "Kenyan") terms. If "non-ethnics" are the most geographically and economically mobile elements in Kenyan society, then a transformation of ethnic voting into policy voting would seem to require further social structural change, including greater contact and integration among ethnic groups. In this light, the post-election phenomenon of ethnic cleansing, in which migrant populations have been forced back into their provinces of origin, does not augur well for the further development of interest-based voting or democratic politics in Kenya.

\section{References}

[1] Apollos, Machira. "Ethnicity, Violence and Democracy," Africa Development, Vol. XXVI, no. 1 and 2 (2001):99-144.

[2] Birnir, Johanna, Ethnicity and Electoral Politics (New York: Cambridge University Press, 2007).

[3] Bratton, Michael, Robert Mattes and E. Gyimah-Boadi, Public Opinion, Democracy and Market Reform in Africa (New York: Cambridge University Press, 2005).

[4] Chandra, Kanchan, Why Ethnic Parties Succeed: Patronage and Ethnic Head Counts in India (New York,Cambridge University Press, 2003)

[5] Erdmann, Gero. "The Cleavage Model, Ethnicity and Voter Alignment in Africa: Conceptual and Methodological Problems Revisited," GIGA Working Papers, Working Paper No. 63, December (2007).

[6] Ferree, Karen E. . "The Micro-Foundations of Ethnic Voting: Evidence From South Africa," Afrobarometer Working Paper, no. 40, June (2004).

[7] Ferree, Karen, T The Political Origins of South Africa's Racial Census. New York, Cambridge University Press, forthcoming 2008.

[8] Kalipeni, Ezekiel "Regional Polarisation in Voting Pattern: Malawi's 1994 Elections," African Journal of Political Science, 2, no. 1 (1997): 152-167. 
[9] Geys, B. "Explaining Voter Turnout: A Review of Aggregate-Level Research," Electoral Studies 25. 4, (2006): 637-663.

[10] Kimenyi, Mwangi S. Ethnic Diversity, Liberty and the State: The African Dilemma, Cheltenham, Eng: Edward Elgar: 1997.

[11] Kimenyi, Mwangi S. and Ndung'u, Njuguna, S., "Sporadic Ethnic Violence: Why Has Kenya Not Experienced a full-blown Civil War?" in P. Collier and N. Sambanis (eds), Understanding Civil War (Vol. 1: Africa), World Bank: Washington, D.C., 2005.

[12] Kimenyi, Mwangi S. and Shughart, William F., "The Political Economy of Constitutional Choice: A Study of the 2005 Kenyan Constitutional Referendum," Working Paper, Department of Economics, The Univeristy of Connecticut, 2008.

[13] Lewis-Beck, Michael S. and Stegmaier, Mary. "Economic Determinants of Electoral Outcomes," Annual Review of Political Science, Vol. 3 (2000): 183-219.

[14] Lichbach, Mark and Alan Zuckerman, Comparative Politics: Rationality, Culture and Structure (New York: Cambridge University Press, 1997).

[15] Lindberg, Staffan I. and Morrison, Minion K.C., "Are African Voters Really Ethnic or Clientelistic? Survey Evidence from Ghana," Political Science Quarterly, 123, Spring (2008), Forthcoming.

[16] Mattes, Robert and Jessica Piombo, "Opposition Parties and the Voters in South Africa's General Election of 1999," Democratization 8, 3: 101-128.

[17] Muigai, Githu. "Ethnicity and the Renewal of Competitive Politics in Kenya," in Harvey Glickman, ed. Ethnic Conflict and Democratization, Atlanta, GA: The African Studies Association Press, 1995, 161-96.

[18] Norris, Pippa and Mattes, Robert, "Does Ethnicity Determine Support for the Governing Party," Working Paper, John F. Kennedy School of Government, 2003.

[19] Nugent, Paul. "Ethnicity as an Explanatory Factor in the Ghana 2000 Elections," African Issues, 29, No. 1/2 (2001): 2-7.

[20] Nugent, Paul. Africa Since Independence Houndmills, Basingstoke: Palgrave Macmillan, 2004.

[21] Orvis, Stephen. "Moral Ethnicity and Political Tribalism in Kenya's 'Virtual Democracy'," African Issues, 29, No. 1/2 (2001): 8-13.

[22] Oyugi, Walter O. "Ethnicity in the Electoral Process: The 1992 General Elections in Kenya," African Journal of Political Science 2, no 1 (1997): 41-69. 
[23] Pacek, A. and B. Radcliff, "Economic Voting and the Welfare State: A Cross-National Analysis," Journal of Politics, 38 (1995): 723-44.

[24] Posner, Daniel, Institutions and Ethnic Politics in Africa. New York: Cambridge University Press, 2005.

[25] Posner, Daniel and Simon, David J. "Economic Conditions and Incumbent Support in Africa's New Democracies: Evidence from Zambia," Comparative Political Studies, 35, no 3 (2002): 313-336.

[26] Remmer, Karen, "The Political Impact of Economic Crisis in Latin America in the 1980s", American Political Science Review, 85 (1991): 777-800.

[27] Youde, Jeremy (2005), "Economics and Government Popularity in Ghana," Electoral Studies 24, no 1 (2005): 1-16. 